\title{
Microhabitat Occupation by Birds in a Restinga Fragment of Paraná Coast, PR, Brazil
}

\author{
Nelson Novaes Pedroso Junior ${ }^{*}$ \\ Laboratório de Biologia da Conservação; Centro de Estudos do Mar; UFPR; Av. Beira-Mar s/n; 83255-971; \\ C.P. 50002; nelson@cem.ufpr.br; Balneário Pontaldo Sul; Pontal do Paraná - PR - Brazil
}

\begin{abstract}
Studies were carried out to characterize microhabitat occupation by birds in a restinga fragment of Paraná coast. Were described 14 microhabitats occupied in different manners for 64 species of birds. Based on the results, could be suggested that this conspicuous class of vertebrates, together with the other elements that integrate the restinga, serve as a component to attract and stimulate the interest for the comprehension and necessity of conservation by the visitors of such ecosystem.
\end{abstract}

Key words: Microhabitat, birds, restinga, sand ridges, conservation

\section{INTRODUCTION}

The term restinga was used by Rizzini (1963) to describe also the littoral vegetation complex and one of its subsections, and even a particular type of vegetation (coastal forest). From the geological point of view, for instance, the term restinga is used to define the littoral sand ridges, as well as to designate sandy deposits of different origins (Suguio and Tessler, 1984). Due to the complexity of the sedimentary processes involved in the formation of restinga ridges, which results in complex environmental mosaics, and since they are natural areas previously created, the vegetation shows to be very diverse from the physiognomic, structural and sucessional points of view, containing several microhabitats. This complexity allows the existence of different animal populations may coexist in the same place, but with structurally distinct microhabitats.
In spite of this, studies focusing the avifauna associated with the restinga ecosystem have been very scarce (Maciel 1984; Porto and Teixeira 1984), which concluded that the restinga avifauna is result of a mosaic of environments that composed it. Cerqueira (1984) accepted that the restinga is a extension of the distribution of many bird species and, due to continuous destruction of the Brazilian littoral, it would be necessary to preserve it.

This study characterizes the portion of restinga of the littoral of Paraná, considered by the Brazilian environmental legislation as Permanent Preservational Area (Law 4771, Art. 2.). This also characterizes the richness and the diversity of bird's species, analyzing and comparing the differential occupation of the microhabitats by them, besides investigating aspects of environmental conservation.

\footnotetext{
* Author for correspondence
} 


\section{MATERIALS AND METHODS}

\section{Study Area}

Pontal do Sul is located on the South Bar of the Bay of Paranaguá and has its limits in north and east with the waters of the Bay, in south with the Atlantic Ocean, and in west to the continental lands (Figure 1- A). The region has been suffering changes on the coastline, which the last 40 years has been migrating very strongly to east, and during at point, progressed more than 700 meters with a mean advance of $17.5 \mathrm{~m} /$ year (Soares et al., 1994). The exploration of real estate agencies since 1951, when it was first created, was also responsible for structural and functional modifications of the ecosystem. The studies were done on a portion of restinga ridges that occupied an area just recently prograded (FUNPAR, 1999).

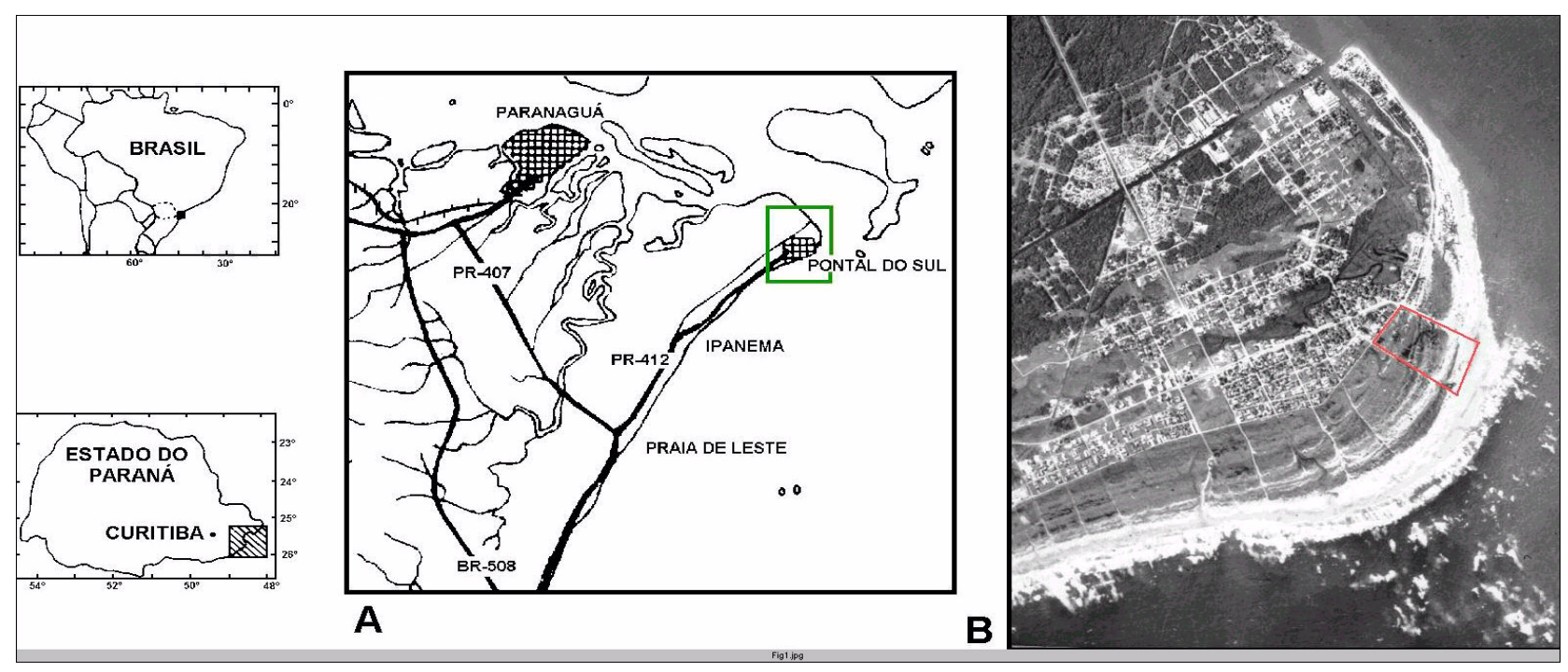

Figure 1 - (A) Localization of the study area. (B) Study area

Delimited by one side by the Atlantic Ocean and by the other, by the Balneary Pontal do Sul (Figure 1-B). The littoral sands began to be colonized by the vegetation from the primary dune ridges, where developed a pioneer community of psammophilous species (Bigarella et al.1969). An unevenness on the ground conducts to a small inter-ridges plains covered by grasses mainly. Next sand ridge towards the interior of the continent is higher than the first. On this secondary dune ridge, the vegetation is a little more developed than in the first being distributed in a discontinuous form with shrubby vegetation and thin herbaceous and even absent vegetation with exposed sand. After this portion of dunes there is a sandy plain where are the fields intermingled by

\section{Methods}

For the realization of the studies, three transversal transects were delineated to the coastline from the Avenue Mira-Mar (which delimited the restinga to lead off the parcels) until the sandy beach, parallel patches of low size forest, marshes and internal dunes Rambo (1956). The conditions of drainage determine two main types of sandy fields: the dry and the humid ones. The marshes, or inter-ridges swamps, occur on shallow, narrow and long depressions, with width smaller than $100 \mathrm{~m}$ on these depressions. The drainage is very slow with characteristic vegetation of Cyperaceae, mostly of the genus Cladium and Scirpus californicus (dominant species), besides the grass, Juncaceae and others (Klein, 1975). The internal dunes that develop over the sandy plain conserve the psammophilous vegetation. The last sand ridge was referred as "the oldest ridge" by Bigarella et al.(1969). The vegetal cover is more dense, constituted by low/small size trees and bushes.

and equidistant 75 meters one from another in a total area of $72,000 \mathrm{~m}^{2}$ (Figure 1-B). Each transect was marked with 9 points, with a distance of 60 meters from each other, beginning in the avenue and finishing at the beginning of the sandy beaches being the first right on the beginning of the vegetation, and so-called "point 1", and thus 
successively until the last point passing through a total distance of 480 meters.

The field method was done in two phases. The first, lasting for a week, consisted of identification of the birds seen or heard in the area by general observations, that means not obeying a predetermined pattern, besides the familiarization and description of the environment. The second phase was carried out in the months of July and October, 1997 and January and April 1998.

manners of use and its degradation of, all in a standard time (approximately 5 minutes for each point of the transect).

For determining the relative frequency $(f)$, it the number of census that each species appeared $(n c)$ was divided by the total number of census done (tc) and was multiplied with 100 , according to the formula: $\mathrm{f}=\mathrm{nc} / \mathrm{tc} \times 100$. The abundance index $(a)$ was calculated dividing the total number of contacts with the species (ne), by the total number of hours of the effected census (thc), according to the formula: $\mathrm{a}=$ ne/thc.

The taxonomic order and the scientific nomenclature follow the proposed by Sick (1997).

\section{RESULTS AND DISCUSSION}

It was possible to identify on the studied area 4 environments: 1) primary dunes, 2) secondary dunes, 3) sandy plain and 4) older dunes. These were then divided again into microhabitats, according to the table 1 .

A total of 64 species of birds were identified, which belonged to 24 families, of which $54.7 \%$ were members of the Passeriform order. The forms with bigger relative frequency and abundance index were Zonotrichia capensis, Leistes superciliaris, Certhiaxis cinnamomea, Speotyto cunicularia, Anthus lutescens, Vanellus chilensis, Troglodytes aedon, Pitangus sulphuratus and Porzana albicollis (Table 2). On the other hand, $64 \%$ of the species showed relative frequency smaller or equal to $20 \%$, meaning that many of them did not live on these environments, but used them at any time of the year or sporadically as complementary source of food, shelter and rest during the migratory displacements and recruitment of the young forms. The species that occupied the biggest number of microhabitats was $Z$. capensis (11). Interestingly, 13 species were registered occupying only one microhabitat each (Table 2). Only C. cinnamomea showed
The observations were made with the help of binoculars in two daily sessions, one in the dawn and the other at the nightfall, passing through one transect by period (approximately 90 minutes a day, 45 minutes for each session), and a total of 76 census were carried out for 57 hours. This phase allowed the description of each of the microhabitats and the identification and the counting of the seen birds, as well as the microhabitat that they used to occupy, concomitantly high indexes of abundance and relative frequency, because it was a resident bird restricted to tufts of vegetation in the inter-ridges swamps. This microhabitat was characterized as "marshes, tufts of Scirpus" (MTS). The microhabitat that showed biggest richness and abundance of birds was the one composed by "arboreal shrubbery vegetation" (ASV), which comprised 31 species, representing $48.4 \%$ of the total (Table 3). But, only 12 of the 31 species registered in this microhabitat showed relative frequency superior to $20 \%$ and, from these only $Z$. capensis, T. aedon and $P$. sulphuratus had a value over $50 \%$ (Table 2). This could be a reflex of its location together with the other three that composed the environment of the oldest dunes, "shrubbery field" (SF), "dirty field" (DF) and "sandy exposed floor" (SEF) on the adjacencies of the parcels. This showed that the area received visits of the sinanthropous birds proceeding from urban environments on a study developed by Moraes (1995) were often visited by 76 species of birds. These four microhabitats still received visits of birds proceeding from the sandy and paludous forests and from mangroves close to the studied area. One of them, Polystictus pectoralis, has been considered an endangered species in Paraná (Law $\left.\mathrm{n}^{\mathrm{o}} 11.067,17 / 02 / 95\right)$.

Another microhabitat greatly occupied by birds was the "marshes, tufts of Scirpus " (MTS), which sheltered 14 species. This value was inferior to the "humid field" (HF) and of the "dry field" (BF), but with an abundance index of birds slightly bigger than the previous ones (Table 3). This abundance was due to the presence of two species, $C$. cinnamomea and $P$. albicollis, resident and restricted to the microhabitat. Besides that tufts of swampy vegetation served as elevated perch for several species, that use them to sight prey and/or predators, rest, accomplishing ritual of court or feeding during its period of fructification. This microhabitat was part of a bigger environment, the sandy plain between the secondary dune ridges 
and the one of the oldest ridges. The area that can also be denominated as "inter-ridges swamps", and bear the areas of marshes, dry and humid fields and low dunes scattered through the plain.

Table 1 - Characterization of the microhabitats on the study area.

\begin{tabular}{|c|c|c|c|}
\hline Environment & \multicolumn{2}{|l|}{ Microhabitat } & Abbrev \\
\hline A) Primary & \multicolumn{2}{|l|}{ Sandy beach } & SB \\
\hline dunes & \multicolumn{2}{|l|}{ Pioneer vegetal community } & PVC \\
\hline B) Secondary & \multicolumn{2}{|l|}{ Exposed sand } & ES \\
\hline dunes & \multicolumn{2}{|l|}{ Low vegetation, mainly with } & LV \\
\hline & \multicolumn{2}{|l|}{ grass and some shrubs } & \\
\hline \multirow[t]{6}{*}{ C) Sand plain } & \multicolumn{2}{|l|}{ Dry field } & DRF \\
\hline & \multicolumn{2}{|l|}{ Humid field } & $\mathrm{HF}$ \\
\hline & \multicolumn{2}{|c|}{ Shallow dunes scattered on the grass } & SDG \\
\hline & 1 & low bush & SDB \\
\hline & \multirow[t]{2}{*}{ Marshes with: } & exposed water & MW \\
\hline & & tufts ofScirpus & MTS \\
\hline \multirow{4}{*}{$\begin{array}{l}\text { D) Older } \\
\text { Dunes }\end{array}$} & \multicolumn{2}{|l|}{ Arboreal shrubbery vegetation } & ASV \\
\hline & \multicolumn{2}{|l|}{ Shrubbery field } & SF \\
\hline & \multicolumn{2}{|l|}{ Sandy exposed vegetation } & SEV \\
\hline & \multicolumn{2}{|l|}{$\begin{array}{l}\text { Dirty field between the } 2 \text { older } \\
\text { Dune ridges }\end{array}$} & DIF \\
\hline
\end{tabular}

Table 2 - Distribution of the species across the microhabitats, using frequency (\%). Each species has two values, the first one corresponds to the distribution of a species across the fourteen microhabitats (the total per line is $100 \%$ ). The second value (under it), corresponds to the distribution of all species across determinated microhabitat (the total per column is $100 \%)$. The last two columns correspond to the total relative frequency $(f)$ and the total abundance index $(a)$ of the species registered in the study area

\begin{tabular}{|c|c|c|c|c|c|c|c|c|c|c|c|c|c|c|c|c|}
\hline \multirow[b]{2}{*}{ SPECIES } & \multicolumn{14}{|c|}{ MICROHABITAT } & \multirow[b]{2}{*}{$(f)$} & \multirow[b]{2}{*}{ (a) } \\
\hline & SB & $\mathrm{PVC}$ & ES & LV & DRF & $\mathrm{HF}$ & $\mathrm{SDG}$ & SDS & MTS & MW & ASV & $\mathrm{SEV}$ & DIF & SF & & \\
\hline Casmerodius albus & & & & & $\begin{array}{c}11,8 \\
2,9\end{array}$ & $\begin{array}{c}76,4 \\
5,2\end{array}$ & & & & $\begin{array}{c}11,8 \\
5,7\end{array}$ & & & & & 19,74 & 0,298 \\
\hline Egretta thula & & $\begin{array}{c}26,7 \\
1,9\end{array}$ & & & & $\begin{array}{c}60,0 \\
3,6\end{array}$ & & & & $\begin{array}{c}13,3 \\
5,7\end{array}$ & & & & & 11,84 & 0,263 \\
\hline Bubulcus ibis & & & & & & $\begin{array}{c}100,0 \\
3,2\end{array}$ & & & & & & & & & 1,32 & 0,140 \\
\hline Syrigma sibilatrix & & & & & $\begin{array}{l}9,1 \\
1,4\end{array}$ & $\begin{array}{c}90,9 \\
4,1\end{array}$ & & & & & & & & & 9,21 & 0,193 \\
\hline Cathartes aura & & $\begin{array}{c}50,0 \\
0,5\end{array}$ & & & & & & & & & & & & & 1,32 & 0,035 \\
\hline Amazonetta brasiliensis & & & & & & $\begin{array}{c}21,9 \\
2,8\end{array}$ & & & & $\begin{array}{c}78,1 \\
1,4\end{array}$ & & & & & 19,74 & 0,561 \\
\hline Milvago chimachima & & & & & & & & & & & $\begin{array}{c}100,0 \\
0,2\end{array}$ & & & & 1,32 & 0,018 \\
\hline Polyborus plancus & & $\begin{array}{c}40,0 \\
1,0\end{array}$ & & & & & & & & & & & & & 6,58 & 0,088 \\
\hline Porzana albicollis & & & & & & $\begin{array}{c}10,4 \\
2,8\end{array}$ & & & $\begin{array}{c}88,2 \\
6,4\end{array}$ & & & & $\begin{array}{l}1,5 \\
1,3\end{array}$ & & 56,58 & 1,175 \\
\hline Laterallus melanophaius & & & & & & $\begin{array}{c}20,0 \\
0,4\end{array}$ & & & $\begin{array}{c}80,0 \\
1,1\end{array}$ & & & & & & 6,58 & 0,088 \\
\hline Gallinula chloropus & & & & & & $\begin{array}{c}25,0 \\
0,4\end{array}$ & & & & $\begin{array}{c}75,0 \\
8,6\end{array}$ & & & & & 5,26 & 0,070 \\
\hline Jacana jacana & & & & & & $\begin{array}{c}100,0 \\
0,8\end{array}$ & & & & & & & & & 2,63 & 0,035 \\
\hline Vanellus chilensis & $\begin{array}{l}1,3 \\
2,0\end{array}$ & $\begin{array}{l}32,0 \\
23,4\end{array}$ & $\begin{array}{c}27,5 \\
7,8\end{array}$ & $\begin{array}{c}6,5 \\
16,4\end{array}$ & $\begin{array}{l}0,7 \\
1,4\end{array}$ & $\begin{array}{l}28,7 \\
17,8\end{array}$ & $\begin{array}{l}3,3 \\
8,2\end{array}$ & & & & & & & & 76,32 & 2,684 \\
\hline Charadrius semipalmatus & $\begin{array}{c}80,0 \\
8,2\end{array}$ & $\begin{array}{c}20,0 \\
1,0\end{array}$ & & & & & & & & & & & & & 3,95 & 0,175 \\
\hline C. collaris & $\begin{array}{l}33,8 \\
23,8\end{array}$ & $\begin{array}{l}64,7 \\
21,0\end{array}$ & $\begin{array}{l}1,5 \\
0,7\end{array}$ & & & & & & & & & & & & 38,16 & 1,193 \\
\hline Tringa solitaria & $\begin{array}{c}100,0 \\
2,0\end{array}$ & & & & & & & & & & & & & & 2,63 & 0,035 \\
\hline T. flavipes & $\begin{array}{c}100,0 \\
4,1\end{array}$ & & & & & & & & & & & & & & 2,63 & 0,070 \\
\hline Calidris sp & $\begin{array}{c}50,0 \\
1,0 \\
\end{array}$ & $\begin{array}{c}50,0 \\
0,5 \\
\end{array}$ & & & & & & & & & & & & & 2,63 & 0,035 \\
\hline
\end{tabular}


(Cont. Table 2)

\begin{tabular}{|c|c|c|c|c|c|c|c|c|c|c|c|c|c|c|c|c|}
\hline \multirow[b]{2}{*}{ SPECIES } & \multicolumn{14}{|c|}{ MICROHABITAT } & \multirow[b]{2}{*}{$(f)$} & \multirow[b]{2}{*}{ (a) } \\
\hline & SB & PVC & ES & LV & DRF & HF & SDG & SDS & MTS & MW & ASV & SEV & DIF & SF & & \\
\hline Gallinago paraguaiae & & & & & $\begin{array}{l}6,2 \\
5,8\end{array}$ & $\begin{array}{l}87,5 \\
22,6\end{array}$ & $\begin{array}{l}1,6 \\
1,6\end{array}$ & & & $\begin{array}{l}4,7 \\
8,6\end{array}$ & & & & & 43,42 & 1,123 \\
\hline Larus dominicanus & $\begin{array}{l}81,8 \\
27,9\end{array}$ & $\begin{array}{c}18,2 \\
2,9\end{array}$ & & & & & & & & & & & & & 3,95 & 0,579 \\
\hline Crotophaga ani & & & & & $\begin{array}{l}5,5 \\
1,4\end{array}$ & & & $\begin{array}{c}11,1 \\
2,1\end{array}$ & $\begin{array}{c}38,9 \\
1,9\end{array}$ & & $\begin{array}{c}16,7 \\
0,5\end{array}$ & & $\begin{array}{c}27,8 \\
6,5\end{array}$ & & 15,79 & 0,316 \\
\hline Speotyto cunicularia & & & $\begin{array}{l}90,9 \\
53,0\end{array}$ & $\begin{array}{l}6,8 \\
9,8\end{array}$ & & & & $\begin{array}{l}2,3 \\
2,1\end{array}$ & & & & & & & 61,84 & 1,544 \\
\hline Streptoprocne zonaris & $\begin{array}{c}100,0 \\
1,0\end{array}$ & & & & & & & & & & & & & & 1,32 & 0,526 \\
\hline Melanotrochilus fuscus & & & & & & & & & & & & & & $\begin{array}{c}100,0 \\
0,5\end{array}$ & 1,32 & 0,018 \\
\hline Chlorostilbon aureoventris & & & & & & & & & & & & & & $\begin{array}{c}100,0 \\
1,0\end{array}$ & 2,63 & 0,035 \\
\hline Amazilia versicolor & & & & & & & & & & & $\begin{array}{c}66,7 \\
1,0\end{array}$ & & $\begin{array}{c}22,2 \\
2,6\end{array}$ & $\begin{array}{c}11,1 \\
0,5\end{array}$ & 10,53 & 0,158 \\
\hline Trochilidae & & & & & & & & & $\begin{array}{c}40,0 \\
0,6\end{array}$ & & $\begin{array}{c}60,0 \\
0,5\end{array}$ & & & & 5,26 & 0,088 \\
\hline Colaptes campestris & & & $\begin{array}{l}3,7 \\
1,3\end{array}$ & $\begin{array}{l}9,3 \\
8,2\end{array}$ & & & $\begin{array}{l}3,7 \\
3,3\end{array}$ & $\begin{array}{l}1,8 \\
1,0\end{array}$ & & & $\begin{array}{c}70,4 \\
6,4\end{array}$ & $\begin{array}{c}9,3 \\
12,8\end{array}$ & $\begin{array}{l}1,8 \\
1,3\end{array}$ & & 25,0 & 0,947 \\
\hline Furnarius rufus & & & & & & & & & & & $\begin{array}{c}35,3 \\
1,0\end{array}$ & $\begin{array}{l}52,9 \\
23,0\end{array}$ & $\begin{array}{l}5,9 \\
1,3\end{array}$ & $\begin{array}{l}5,9 \\
0,5\end{array}$ & 15,79 & 0,298 \\
\hline Synallaxis spixi & & & & & & & & & & & $\begin{array}{c}90,5 \\
3,2\end{array}$ & & & $\begin{array}{l}9,5 \\
1,0\end{array}$ & 26,32 & 0,368 \\
\hline Certhiaxis cinnamomea & & & & & & & & & $\begin{array}{c}100,0 \\
30,5\end{array}$ & & & & & & 86,84 & 1,930 \\
\hline Camptostoma obsoletum & & & & & & & & $\begin{array}{c}11,1 \\
3,2\end{array}$ & & & $\begin{array}{c}63,0 \\
2,8\end{array}$ & & & $\begin{array}{c}25,9 \\
3,4\end{array}$ & 23,68 & 0,474 \\
\hline Elaenia flavogaster & & & & & & & & & & & $\begin{array}{c}92,2 \\
7,9\end{array}$ & & & $\begin{array}{l}7,8 \\
1,9\end{array}$ & 38,16 & 0,895 \\
\hline Serpophaga subcristata & & & & & & & & & & & $\begin{array}{c}28,6 \\
0,3\end{array}$ & & & $\begin{array}{c}71,4 \\
2,4\end{array}$ & 11,84 & 0,123 \\
\hline Polystictus pectoralis & & & & & & & & & & & $\begin{array}{c}60,0 \\
0,5\end{array}$ & & & $\begin{array}{c}40,0 \\
1,0\end{array}$ & 3,95 & 0,088 \\
\hline Pyrocephalus rubinus & & & & & & & & & & & & & & $\begin{array}{c}100,0 \\
1,0\end{array}$ & 2,63 & 0,035 \\
\hline Satrapa icterophrys & & & & & & & & & & & & & $\begin{array}{c}100,0 \\
2,6\end{array}$ & & 1,32 & 0,018 \\
\hline Hirundinea ferruginea & & & & & & & & & & & $\begin{array}{c}100,0 \\
0,2\end{array}$ & & & & 1,32 & 0,018 \\
\hline Machetornis rixosus & & & & & & & & & & & $\begin{array}{c}50,0 \\
0,5\end{array}$ & & & $\begin{array}{c}50,0 \\
1,4\end{array}$ & 2,63 & 0,105 \\
\hline Myiarchus sp & & & & & & & & & & & $\begin{array}{c}50,0 \\
0,3\end{array}$ & & & $\begin{array}{c}50,0 \\
1,0\end{array}$ & 3,95 & 0,070 \\
\hline Pitangus sulphuratus & & & & $\begin{array}{l}0,9 \\
1,7\end{array}$ & & $\begin{array}{l}1,8 \\
0,8\end{array}$ & & $\begin{array}{l}2,7 \\
3,2\end{array}$ & $\begin{array}{l}41,9 \\
12,8\end{array}$ & & $\begin{array}{c}49,1 \\
9,0\end{array}$ & & $\begin{array}{l}3,6 \\
5,2\end{array}$ & & 63,16 & 1,930 \\
\hline Myiozetetes similis & & & & & & & & & & & $\begin{array}{c}100,0 \\
0,8\end{array}$ & & & & 3,95 & 0,088 \\
\hline Tyrannus savana & & & & & & & & & $\begin{array}{c}25,0 \\
0,6\end{array}$ & & $\begin{array}{c}75,0 \\
1,0\end{array}$ & & & & 7,89 & 0,140 \\
\hline T. melancholicus & & & & & & & & & $\begin{array}{c}22,2 \\
1,6\end{array}$ & & $\begin{array}{c}74,1 \\
3,3\end{array}$ & & & $\begin{array}{l}3,7 \\
0,5\end{array}$ & 21,05 & 0,474 \\
\hline Tachycineta leucorrhoa & $*$ & $*$ & * & $*$ & $*$ & $*$ & * & $*$ & $*$ & $*$ & $*$ & $*$ & * & $*$ & $*$ & $*$ \\
\hline Progne chalybea & * & * & * & * & * & * & * & $*$ & $*$ & * & $*$ & * & * & $*$ & * & $*$ \\
\hline Notiochelidon cyanoleuca & $*$ & $*$ & $*$ & $*$ & $*$ & * & * & $*$ & $*$ & $*$ & $*$ & $*$ & $*$ & $*$ & $*$ & $*$ \\
\hline Troglodytes aedon & & & & $\begin{array}{l}1,1 \\
1,7\end{array}$ & & & & $\begin{array}{l}3,3 \\
3,2\end{array}$ & & & $\begin{array}{c}46,7 \\
7,2\end{array}$ & $\begin{array}{l}1,1 \\
2,6\end{array}$ & $\begin{array}{c}8,7 \\
10,4\end{array}$ & $\begin{array}{l}39,1 \\
17,3\end{array}$ & 69,74 & 1,614 \\
\hline Turdus rufiventris & & & & & & & & & & & $\begin{array}{c}57,1 \\
0,7\end{array}$ & $\begin{array}{c}14,3 \\
2,6\end{array}$ & $\begin{array}{c}28,6 \\
2,6\end{array}$ & & 6,58 & 0,123 \\
\hline T. amaurochalinus & & & & & & & & & $\begin{array}{l}5,7 \\
0,6\end{array}$ & & $\begin{array}{c}94,3 \\
5,5\end{array}$ & & & & 30,26 & 0,614 \\
\hline Mimus triurus & & & & & & & & & & & $\begin{array}{c}88,9 \\
1,3\end{array}$ & & & $\begin{array}{c}11,1 \\
0,5\end{array}$ & 11,84 & 0,158 \\
\hline Anthus lutescens & & $\begin{array}{l}64,4 \\
40,6\end{array}$ & $\begin{array}{l}0,7 \\
0,7\end{array}$ & $\begin{array}{l}4,6 \\
9,8\end{array}$ & $\begin{array}{c}7,6 \\
14,5\end{array}$ & $\begin{array}{l}1,5 \\
0,8\end{array}$ & $\begin{array}{l}21,2 \\
45,9\end{array}$ & & & & & & & & 82,89 & 2,316 \\
\hline Geothlypis aequinoctialis & & & & & & & & $\begin{array}{l}2,0 \\
1,0\end{array}$ & $\begin{array}{c}20,4 \\
2,8\end{array}$ & & $\begin{array}{c}69,4 \\
5,7\end{array}$ & & $\begin{array}{l}8,2 \\
5,2\end{array}$ & & 43,42 & 0,860 \\
\hline Coereba flaveola & & & & & & & & & & & $\begin{array}{c}33,3 \\
0,2\end{array}$ & & & $\begin{array}{c}66,7 \\
0,9\end{array}$ & 3,95 & 0,053 \\
\hline Ramphocelus bresilius & & & & & & & & & & & $\begin{array}{c}100,0 \\
0,3\end{array}$ & & & & 2,63 & 0,035 \\
\hline Thraupis sayaca & & & & & & & & & & & $\begin{array}{c}68,5 \\
6,2\end{array}$ & & & $\begin{array}{c}31,5 \\
8,1\end{array}$ & 31,58 & 0,947 \\
\hline Zonotrichia capensis & & & $\begin{array}{l}2,1 \\
6,6\end{array}$ & $\begin{array}{c}4,5 \\
36,0\end{array}$ & $\begin{array}{l}1,0 \\
7,3\end{array}$ & $\begin{array}{l}1,0 \\
2,0\end{array}$ & $\begin{array}{c}4,3 \\
34,4\end{array}$ & $\begin{array}{c}11,1 \\
6,8\end{array}$ & $\begin{array}{l}14,3 \\
19,2\end{array}$ & & $\begin{array}{l}28,9 \\
23,4\end{array}$ & $\begin{array}{c}4,5 \\
56,4\end{array}$ & $\begin{array}{c}4,8 \\
29,9\end{array}$ & $\begin{array}{l}23,5 \\
55,0\end{array}$ & 100,0 & 8,509 \\
\hline Sporophila caerulescens & & & & & & & & 14,3 & & & & & 57,1 & 28,6 & 9,21 & 0,123 \\
\hline
\end{tabular}




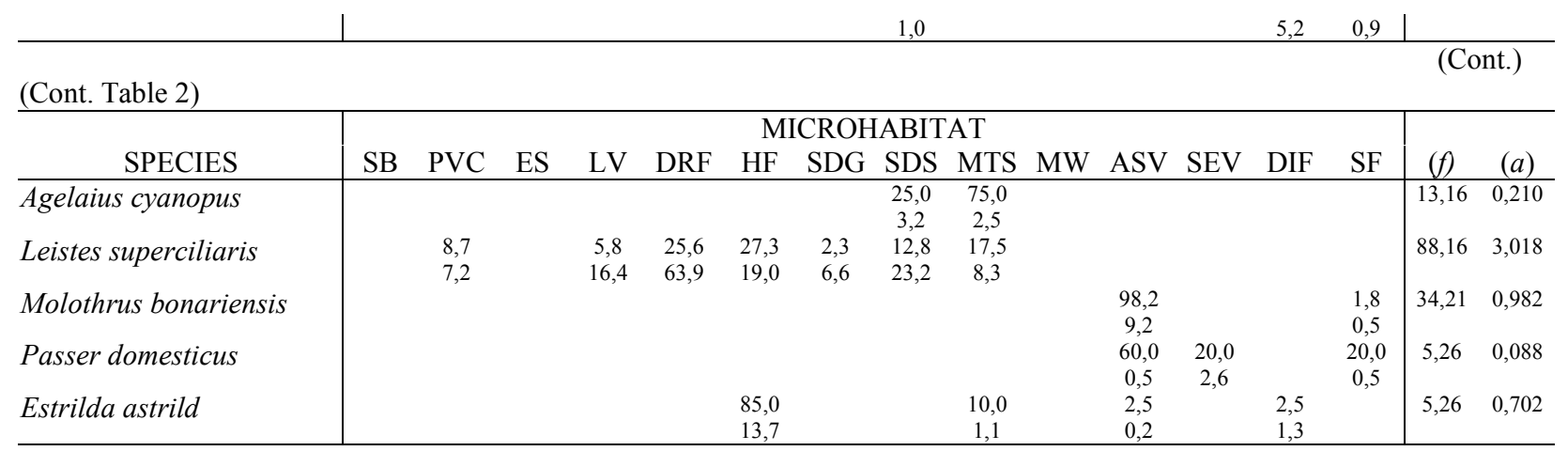

* : species that forage on the air stratum

Table 3 - Richness and abundance of bird species by microhabitat.

\begin{tabular}{c|cccc}
\hline micro-habitat & number of individuals & abundance index & number of species & \% of species \\
\hline SB & 97 & 1,70 & 08 & 12,5 \\
PVC & 209 & 3,67 & 10 & 15,6 \\
ES & 151 & 2,65 & 07 & 10,9 \\
LV & 61 & 0,53 & 08 & 12,5 \\
DRF & 69 & 1,21 & 09 & 14,1 \\
HF & 248 & 4,35 & 16 & 25,0 \\
SDG & 61 & 1,07 & 06 & 9,4 \\
SDS & 95 & 1,67 & 11 & 17,2 \\
MTS & 360 & 6,32 & 14 & 21,9 \\
MW & 35 & 0,61 & 05 & 7,8 \\
ASV & 598 & 10,50 & 31 & 48,4 \\
SEV & 39 & 0,68 & 06 & 9,4 \\
DIF & 77 & 1,35 & 14 & 21,9 \\
SF & 207 & 3,63 & 21 & 32,8 \\
total & 2307 & 40,47 & 64 & 100 \\
\hline
\end{tabular}

Moraes (1995) registered 57 species of birds in this environment, in contrast to the 25 species verified on the present study, which could be due to the fact that the study area comprised only a small section of the environment at issue. Besides that, this portion comprised the beginning of north limit of the inter-ridges swamps in the Balneary, where more to the South there have been more significant portions of the referred system. Perhaps that was why frequent forms had not been registered on this kind of environment such as Butorides striatus, Porzana flaviventer, Neocrex erythrops, Porphyriops melanops, Fulica sp., and Nicticryphes semicollaris. Referring to the other microhabitats that this environment integrated, the "humid field" presented a considerable abundance of birds, having as typical forms Gallinago paraguaiae and $L$. superciliaris (the last one also being typical of the microhabitat "dry field"). It still was the most used microhabitat by the 4 species of Ardeidae registered, besides the Jacana jacana and Estrilda astrild. If in the marshes the vegetation tufts sheltered the greatest number of species and individuals, the exposed water, not much abundant in the area presented the second smallest abundance index and relative frequency of birds, being occupied mainly by Amazonetta brasiliensis, besides being the most used microhabitat by Gallinula chloropus (Table 2, 3).

On the secondary dunes, the microhabitat composed by "exposed sand" (ES) had a very low richness of species, but the forms that used to frequent this system had high relatively abundance indexes. These could be resident such as $V$. chilensis and $S$. cunicularia, or visitors like Colaptes campestris and Guira guira that foraged at this place. Referring to this microhabitat, it is fundamental to consider its importance to the populations of $S$. cunicularia, which on littoral regions nest preferably on coastal dunes. Perhaps the constant presence of this predatory bird on the secondary dunes may explain the poverty of the 
other species of birds observed on the other adjacent microhabitat, "LV".

The primary dunes had, as more frequent forms, the members of the families Charadriidae, Scolopacidae, Laridae, besides Anthus lutescens, the most frequent bird of the pioneer vegetal community. This environment together with the sandy beach receives direct influence from the sea and, on the contrary to the other portions of the littoral of this State, still are preserved and represent important stopping place for rest and feeding of marine and freshwater birds, migratory or resident.

The three species of swallows Tachycineta leucorrhoa, Progne chalybea and Notiochelidon cyanoleuca that were found, were included in the list of birds, but not in the quantitative analyses, because they foraged in groups, occupying only the air stratum, which made difficult their inclusion on the counting. Polyborus plancus and Cathartes aura were also observed foraging over the area, but always received air raids from groups of $V$. chilensis. There were still a flock of Streptoprocne zonaris, composed by approximately 25 individuals that were feeding on swarms of Dipteran, flying over the primary dunes in October.

\section{CONCLUSION}

From these results, we can justify the conservation of the ridges of restinga. The actual situation of this ecosystem is very critical in our country for being located on the coastal plains that coincidentally shelter or are under direct influence of the biggest urban gathering in the country. At the littoral of Paraná, the main reason that has caused the constant restriction of its area of occurrence is the installation of balnearies following the littoral coast and, consequently the predatory actions resulting from this kind of occupation. In areas increased as the one of this study, the greatest impacts result from fire, vegetation cuts, leveling the terrain as esthetic effect, amplification and enlargement of the access ways to the beach, the movement of sediments for the construction of sports courts and car parks, and the invasion of exotic grasses. Even though law protects areas recently created by natural processes, few are the interested ones on keeping them as they really are. As a proof, there are the projects that aim to parcel or construct car parks and leisure areas on this sort of environment. But, as suggested by Angulo (1993), these areas should not be occupied because they were highly unstable and subjected to the reversion of the sedimentation process, that is, to the erosion process. This conclusion has been corroborated by Soares et al. (1994), who described the protection function which was provided by them to the existing residential neighborhoods, besides constituting a zone of low altitude that on periods of rain were flooded for a long period. McGwinne et al. (1993) also emphasizes the necessity to preserve the environment of dunes and sandy beaches, emphasized that they worked as protection barriers against the amount of energy resulted from the tides and oceanic winds, and mentioning its high scenic and recreational value used by an even greater contingent of people. All the factors discussed above added to the ecological relevance of this environment that nowadays has been extremely restrict and vulnerable, bearing species of plants and animals that have not been recorded in other regions of the State of Paraná.

Birds are possibly the main representatives of the vertebrates on the area for having greater diversity of species and more accentuated conspicuity. Their study becomes more relevant coping with the necessity to assemble enough subsidy to base alternative proposals of sustainable development, having in view the maintenance of the original and natural characteristics and its utilization with this purpose. For so, it is suggested the creation of a conscience on the local residents and tourists, through the elaboration and distribution of pamphlets, divulgation through the written press, practices of environmental education and ecotourism, creation and implantation of interpretative tracks; in other words, which contain information that involve: 1) a brief report about the recent formation of the restinga bundles and its protector function to the adjacent zones and 2) the fauna and flora associated to this sort of environment and its ecological relevance, using the most conspicuous and/or abundant species of birds as representative of different microhabitats. This way, people would be stimulated to observe, contemplate and feel the different forms, colors and sounds that integrate the landscape of this natural area, typical of the littoral of Paraná.

\section{ACKNOWLEDGMENT}


I am thankful to Valéria S. Moraes for her suggestions given during the elaboration, execution and conclusion of this study. Thanks are also done to the Biologists Ricardo Krul and Flávia C. Martins for the help on the field and discussions in the laboratory, to Carlos Soares for the help on the confection of the figures, and to the Center of Marine Sciences for the logistic help.

\section{RESUMO}

Os cordões de restinga formam um ecossistema cuja extensão já se encontra bastante reduzida, devido à sua localização em áreas de grande interesse urbano, industrial e turístico. Nesse estudo caracterizou-se uma parcela desse tipo de ambiente e foram descritos 14 diferentes microhabitats ocupados diferencialmente por 64 espécies de aves. Sugere-se que essa conspícua classe de vertebrados, junto com os demais elementos que integram o ambiente de restinga, sirva como um componente para atrair e estimular o interesse pela compreensão e necessidade de conservação por parte dos frequentadores desse tipo deambiente.

\section{REFERENCES}

Angulo, R. J. (1993), A ocupação urbana do litoral paranaense e as variações da linha de costa. Bol. Par. Geoc., 41, 73-81.

Bertels, M. S. (1957), Monocotiledôneas psamifíticas do litoral do Rio Grande do Sul. Bol. Agronômico, 17, 29-34.

Bigarella, J. J. (1946), Contribuição ao estudo da planície litorânea do Estado do Paraná. Arquivos de Biologia e Tecnologia, 1 : (7), 75-111.

Bigarella, J. J.; Becker, R. D. and Duarte, G. M. (1969), Coastal dune structures from Paraná (Brazil). Marine Geology, 7, 5-55.

Cerqueira, R. (1984), Comunidades animais. In: Lacerda, L. O.; Araujo, D. S. D.; Cerqueira, R. and Turcq, B. (orgs.). Restingas: origem, estrutura $e$ processos. Niterói : CEUFF. pp. 276.

Fundação da Universidade Federal do Paraná. (1999), Diagnóstico do município de Pontal do Paraná, subsídeo para elaboração do plano diretor. Curitiba : FUNPAR. v.1- Diagnóstico. 173 pp.

Instituto Paranaense de Desenvolvimento Econômico e Social. Fundação Édison Vieira. (1989), Zoneamento do litoral paranaense. Curitiba : IPARDES. 175 pp.

Klein, R. M. (1975), Southern brazilian phytogeographic features and the probable influence of upper Quaternary climatic changes in the floristic distribution. Bol. Par. Geoc., 33, 67-88.

Maciel, N. C. (1984), A fauna de restinga do Estado do Rio de Janeiro: passado, presente e futuro. Proposta de preservação. In: Lacerda, L. O.; Araujo, D. S. D.; Cerqueira, R. and Turcq, B. (orgs.). Restingas: origem, estrutura e processos. Niterói : CEUFF. pp. 285-304.

McGwinne, L. E., van Teylingen, K. McLachlan, A. (1993), Coastal dune conservation - Perceptions and needs of management authotities. Institute for Coastal Research. Rep. 32. 19 pp.

Moraes, V. S. and Krul, R. (1995), Aves associadas a ecossistemas de influência marítima no litoral do Paraná. Arq. Biol. Tecnol., 38 (1), 121-134.

Pianka, E. R. (1982), Ecologia Evolutiva. Barcelona : Omega. 365 pp.

Rambo, B. (1956), A flora fanerogâmica dos Aparados Riograndenses. Sellowia, 7, 235-298.

Rizzini, C. T. (1963), Nota prévia sobre a divisão fitogeográfica do Brasil. Rev. Bras. Geografia, 25, 3-64.

Sick, H. (1997), Ornitologia Brasileira. 2. ed. Rio de Janeiro. 912 pp.

Silva Porto, F. C. and Teixeira, D. (1984), Um estudo comparativo preliminar sobre as avifaunas do leste do Brasil. In: Lacerda, L. O.; Araujo, D. S. D.; Cerqueira, R. and Turcq, B. (orgs.). Restingas: origem, estrutura e processos. Niterói : CEUFF. pp. 343-349.

Soares, C.; Paranhos Filho, A. C.; Souza, M. C.; Branco, J. C.; Fabianovicz, R.; Prazeres Filho, H. J. and Kogut, J. S. (1994), Variações da linha de costa no Balneário Pontal do Sul no período 1953-1993: um balanço sedimentar. Bol. Par. Geoc., 42161-171.

Suguio, K. and Tessler, M. G. (1984), Planícies de cordões quaternários do Brasil: origem e nomenclatura. In: Lacerda, L. O.; Araujo, D. S. D.; Cerqueira, R. and Turcq, B. (orgs.). Restingas: origem, estrutura e processos. Niterói : CEUFF. p. 15-26.

Villwock, J. A. (1987), Processos costeiros e a formação das praias arenosas e campos de dunas ao longo da costa Sul e Sudeste brasileira. In: Simpósios sobre ecossistemas da costa Sul e Sudeste brasileira: síntese dos conhecimentos. 1. Cananéia, SP. Academia de Ciências do Estado de São Paulo, ACIESP, 54 : (3), 380-398. 